\title{
DETECTION OF ARSENIC IN ANIMAL FEED CHAIN: BROKEN RICE AND WATER HYACINTH
}

\author{
M. R. Haq, M. M. Rahman, P. Islam, M. A. Awal, S. Chakma and U. K. Roy \\ Department of Pharmacology, Faculty of Veterinary Science, Bangladesh Agricultural University, \\ Mymensinggh-2202, Bangladesh
}

\begin{abstract}
Currently arsenic contamination in Bangladesh is considered to be the biggest natural calamity in the world in the terms of total population affected in an area. Arsenic is spreading in various ways in the environment and significantly threatening the public health as well as animal health of Bangladesh. With a view to detect the level of arsenic concentration in animal feed chain this study was performed by using the FI-HG-AAS (Flow Injection Hydride Generator Atomic Absorption Spectrophotometer) method. Broken rice and water hyacinth samples, two commonly used animal feeds, were collected from arsenic contaminated areas of Comilla district. After collection, the samples were prepared by a series of steps such as, washing, drying and digestion; finally arsenic was detected by atomic absorption spectrophotometric method. Atomic absorption measures the amount of energy absorbed by the samples. Through this method the type of metal absorbed by the sample can be determined. The mean arsenic concentration in broken rice and water hyacinth were $0.213 \pm 0.125 \mathrm{ppm}(\mathrm{n}=35)$ and $0.487 \pm 0.172 \mathrm{ppm}(\mathrm{n}=29)$, respectively. In this study it is found that the level of arsenic both in broken rice and water hyacinth is greater than that of the maximum permissible level in drinking water $(0.05 \mathrm{ppm})$. From the findings of the present study, it can be concluded that in the same arsenic contaminated area, the level of arsenic in water hyacinth is nearly the double of that found in rice due to arsenic accumulating nature of water hyacinth.
\end{abstract}

Key words: Arsenic contamination, broken rice, water hyacinth, Comilla, atomic absorbtion spectrophotometer

\section{INTRODUCTION}

Although arsenic is found in nature in its elemental form (arsenic metal), it occurs most commonly in inorganic or organic compounds. Common inorganic arsenic compounds are trivalent arsenic (e.g., arsenite) and pentavalent arsenic (e.g., arsenate). Common organic arsenic compounds are monomethyl arsonic acid, dimethyl arsenic acid and roxarsone (Lau et al., 1987). Arsenic is a component that is extremely hard to convert to watersoluble or volatile products. The fact that arsenic is naturally a fairly mobile component basically means that large concentrations are not likely to appear on one specific site. This is a good thing, but the negative side to it is that arsenic pollution becomes a wider issue because it easily spreads. Arsenic cannot be mobilized easily when it is immobile. Due to human activities, mainly through mining and melting, naturally immobile arsenics have also mobilized and can now be found on many more places than where they existed naturally (Ministry of Health and Family Welfare Bangladesh).

High arsenic concentration in groundwater is generally associated with the geothermal environments of volcanic deposits, geothermal systems and basin-fill deposits of alluvial lacustrine origin (Welch et al., 1988).

The arsenic disaster of Bangladesh has been called the most terrible environmental catastrophe of the twentieth century. WHO described the condition as "the largest mass poisoning of a population in history" (WHO, 2001). About 85 million people are at risk of drinking arsenic contaminated water and foodstuffs (Hossain, 2006; Wahidur, 2006). In a recent report, Chakraborti et al. (2010) showed that hand tube wells of the tableland and hill tract regions of Bangladesh are primarily free from arsenic contamination, while the flood plain and deltaic region including the coastal region are highly contaminated with arsenic.

Arsenic can enter into food chain causing wide spread distribution throughout the plant and animal kingdoms (Kile et al., 2007). The evidence of arsenic calamity in animal feed chain is scarce. Contamination of animal feed by arsenic is a newly uncovered disaster on a massive scale (Sapkota et al., 2007). This poses a potential dietary risk to human, although little research has focused on food as an additional source of arsenic exposure. Food may contribute up to $30-50 \%$ of the total dietary intake of arsenic when feed is generated from arsenic contaminated

*Corresponding e-mail address: mahmud_ubc@yahoo.ca 


\section{R. Haq and others}

sources (Naidu et al., 2006). Exposure to inorganic arsenic can cause various health effects, such as irritation of the stomach and intestines, decreased production of red and white blood cells, skin changes and lung irritation. It is suggested that the uptake of significant amounts of inorganic arsenic can intensify the chances of cancer development, especially the chances of development of skin cancer, lung cancer, liver cancer and lymphatic cancer (Das et al., 2002). For the above reasons the present study was conducted to detect and estimate arsenic concentration in animal feeds such as broken rice and water hyacinth collected from arsenic contaminated areas of Comilla district.

\section{MATERIALS AND METHODS}

The study was carried out for the detection and estimation of arsenic in broken rice and water hyacinth. The experiment was conducted in the Arsenic Detection and Mitigation (ADM) Laboratory, Department of Pharmacology, Bangladesh Agricultural University (BAU), Mymensingh, Bangladesh.

\section{Study Areas}

In this study, one arsenic contaminated 6 unions (North Eliotgang, South Eliotgong, North Mohammadpur, South Mohammadpur, East Mohammadpur, and West Mohammadpur) in Daudkandi upazilla of Comilla district were selected and animal feed samples such as broken rice and water hyacinth were collected.

\section{Collection of samples}

All required samples were collected during the month of July (rainy season) in the years 2011. In all cases, two types of samples (broken rice and water hyacinth) were collected in the five days of sample collection period. A standardized personal interview of each owner was carried out based on a prearranged questionnaire which included the location, name and address of the person from whom samples were collected and the details of the collected samples.

\section{Broken rice and water hyacinth}

Broken rice and water hyacinth, used as ration for livestock were considered for possible sources of arsenic contamination. Different varieties of broken rice were considered. The grain of broken rice (that generally consumed by dairy cows and poultry) and water hyacinth (consumed by cattle) were collected in zip-type bag, labeled and kept in a polyethylene bag and finally transferred to the laboratory and stored in desiccators until analysis.

\section{Sample preparation and Digestion}

In the laboratory, Department of Pharmacology, BAU, Mymensingh water hyacinth samples were chopped into small pieces for reducing its size. To avoid external contamination and to test actual exposure of arsenic from water hyacinth to cattle, chopped samples were vigorously washed with tap water and finally with distilled water. Broken rice was washed with distilled water and both the samples were oven-dried at $60^{\circ} \mathrm{C}$ for 72 hours. Samples were digested following the method proposed by Wang et al. (2006) with a few modifications. About $0.45-0.50 \mathrm{~g}$ water hyacinth biomass was weighed from bulk sample after further drying at $60^{\circ} \mathrm{C}$ to maintain constant weight. It was taken separately into digestion tube and $7 \mathrm{ml}$ of $69 \%$ concentrated $\mathrm{HNO}_{3}$ was added. The samples left to react overnight in a chemical "hood", then heated in a block digester (M-24 plazas/samples, JP Selecta, Spain) at $120^{\circ} \mathrm{C}$ until colorless clear watery fluid appears. Tubes were gently shaken several times to facilitate destroying all the carbonaceous material. This digestion converts all arsenicals to inorganic arsenic for FI-HG-AAS determination. Digestion was considered complete when production of reddish-orange fumes and foam within the tube had subsided, the solution had become clear and did not bubble or react upon agitation. Tubes were removed from the digestion block, cooled, diluted to $50 \mathrm{ml}$ adding Millipore water and filtered through filter paper (Whatman No. 41) and stored in $50 \mathrm{ml}$ plastic bottles. The sample solution at that stage was ready for determination of its total arsenic. In each set, blank reference material were prepared following same digestion procedures.

\section{Arsenic Detection}

Concentrations of arsenic in digested samples were determined using atomic absorption spectrophotometer (AAS), model PG - 990 equipped with a computer with atomic absorption (AA) Win software (PG Instruments Ltd., UK) following pre-reduction with $\mathrm{KI}$ and $\mathrm{KBH}_{4}$ to generate $\mathrm{AsH}_{3}$ (Samanta et al., 1999). Briefly, samples 
were spiked with standards at different concentrations. For constructing standard curve, working standards of 0 , 2.5, 5, 10, 15 and $20 \mathrm{ppb}$ were prepared immediately before use by serial dilution of the stock in $10 \%$ hydrochloric acid. Samples exceeding the standard curve range were diluted again and analysed further. The concentration of arsenic in those samples was calculated by multiplying the appropriate dilution factor. Sample solution concentrations were determined by direct comparison with the calibration curve and the reading was automatically transferred to AA Win software. Concentration of arsenic in the sample was calculated from the following formula:

Arsenic concentrat ion $(\mathrm{ppm})=\frac{\text { Concentrat ion of arsenic in sample solution }(\mu \mathrm{l}) \times \mathrm{mL} \text { of sample }}{\text { Sample weight }(\mathrm{gm}) \times 1000}$

\section{Statistical Analysis}

The data were analyzed statistically using Student's 't' test as per method described by Bailey (1981).

\section{RESULTS AND DISCUSSION}

Levels of arsenic in broken rice and water hyacinth collected from arsenic contaminated areas.

The results show that concentrations of arsenic in broken rice ranged from 0.08478 to $0.361 \mathrm{ppm}$ with a mean $( \pm$ SEM) value of $0.213 \pm 0.125 \mathrm{ppm}(n=35)$ (Table.1). We found that arsenic concentration in water hyacinth was approximately double than that in rice (Table.1). Concentrations of arsenic in water hyacinth ranged from 0.1266 to $0.9969 \mathrm{ppm}$ with a mean $( \pm \mathrm{SEM})$ value of $0.487 \pm 0.172 \mathrm{ppm}(n=29)$ ( Table. 1$)$.

Table 1. Average concentration of arsenic ( $\mathrm{ppm})$ in broken rice and water hyacinth collected from arsenic contaminated areas of Daudkandi upazilla in Comilla district

\begin{tabular}{|lllll|}
\hline Sample Name & Average & S.D. & S.E.M. & N \\
\hline Broken rice & 0.213744 & 0.74259 & 0.12552 & 35 \\
Water hyacinth & 0.48759 & 0.172372 & 0.032009 & 29 \\
\hline
\end{tabular}

Great fluctuations were found in the concentrations of arsenic in water hyacinth in comparison to that of rice (Figure1). The fluctuations could be due to differences in the absorption and distribution of arsenic in the plant. Moreover, we know that the root of the water hyacinth absorbs and accumulates the highest levels of arsenic than other plants (plants, known for arsenic accumulation/bioindicator, which can effectively remove arsenic and other heavy metals from the aquatic system, for instance, to the tune of 170 and $340 \mu \mathrm{g}$ As/g dry weight of water hyacinth in its stem and leaves, respectively, when grown in a pond containing $10 \mathrm{mg} \mathrm{As} / \mathrm{dm}^{3}$ (Chigbo et al., 1982).

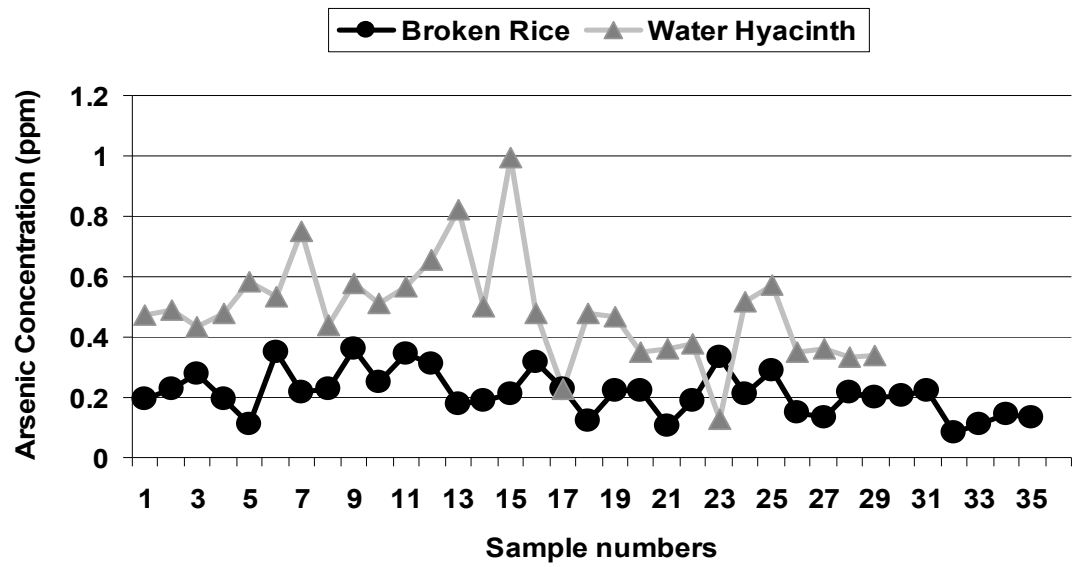

Figure 1. Graphical presentation of arsenic concentration (ppm) in broken rice and water hyacinth collected from arsenic contaminated areas of Daudkandi upazilla of Comilla district 


\section{R. Haq and others}

A comparison of levels of arsenic in shallow tube well water with that of broken rice and water hyacinth collected from arsenic contaminated areas

In this study broken rice and water hyacinth were collected from Daudkandi upazilla in Comilla district and the average concentrations of arsenic were $0.213 \pm 0.125$ and $0.487 \pm 0.172 \mathrm{ppm}$, respectively. Here we find that the water hyacinth accumulated more arsenic than rice and the later accumulated even lesser amount of arsenic than that of the shallow tube well $(\sim 0.455 \mathrm{ppm})$ water of the same area. The average concentrations of arsenic in shallow tube well water and that found in the rice and water hyacinth are tabulated below (Table.2) and graphically presented in the (Figure 2). Similar findings have also been reported by Chakma (2012) who reported that the mean arsenic concentration in rice and rice straw were $0.235 \pm 0.014 \mathrm{ppm}(\mathrm{n}=48)$ and $1.149 \pm 0.119 \mathrm{ppm}$ $(\mathrm{n}=51)$, respectively.

Table 2. A comparison of average arsenic concentration in shallow tubewell water with that found in broken rice and water hyacinth

\begin{tabular}{|lll|}
\hline $\begin{array}{l}\text { As concentration in shallow tube } \\
\text { well water }(\mathrm{ppm})\end{array}$ & $\begin{array}{l}\text { As concentration in broken rice } \\
(\mathrm{ppm})\end{array}$ & $\begin{array}{l}\text { As concentration in water hyacinth } \\
(\mathrm{ppm})\end{array}$ \\
\hline$\sim 0.455^{*}$ & $0.213 \pm 0.125$ & $0.487 \pm 0.172$ \\
\hline Das et al. $(2002)$ & & \\
\hline
\end{tabular}

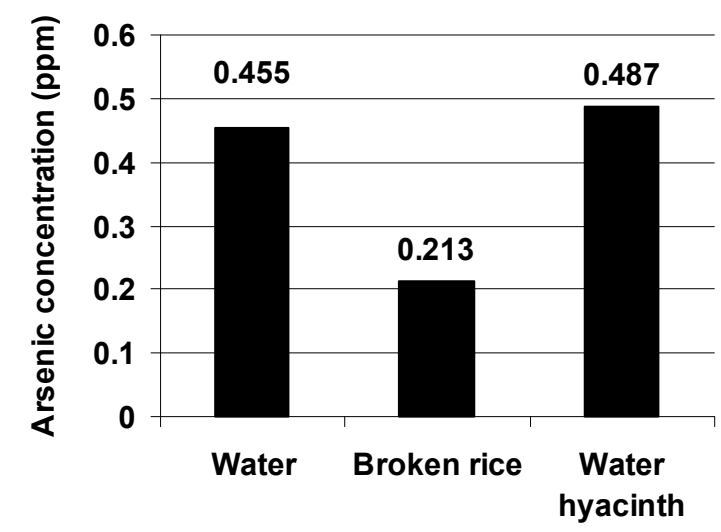

Figure 2. A graphical comparison of average arsenic concentrations (ppm) in shallow tube well water with that found in broken rice and water hyacinth collected from Daudkandi upazilla in Comilla district

It was previously reported that the result of the concentration of As in different parts of rice (Oryza sativa L; verities of Bangladesh namely BRRI dhan 28, BRRI dhan 29, BRRI dhan 35, BRRI dhan 36, BRRI hybrid dhan 1) showed significant increased contents of $A s(P<0.05)$ and the order of As concentration was: straw $>$ Husk $>$ brown rice grain $>$ polish rice grain (Rahman et al., 2007). Another reason could be due to variation in the soil arsenic concentration from plot to plot.

A group based in the Cornell University (USA) carried out an investigation in Brahmanbaria district of Bangladesh and reported that average arsenic concentrations in rice grain and rice straw were 0.45 and 2.00 ppm, respectively (Farid et al., 2005). These figures are approximately the double of what we found in my study. These variations could be due to differences in soil and water arsenic concentrations in different districts of Bangladesh. The Cornell University group also found significant correlations between arsenic contents of soil, grain and straw (Farid et al., 2005).

Another research work carried out in Thailand reported that concentrations of inorganic arsenic in polished white, jasmine and sticky rice were $0.068 \pm 17.6,0.068 \pm 15.6$, and $0.075 \pm 24.8 \mathrm{ppm}$, respectively, while those in the three brown rice samples were $0.124 \pm 34.4,0.120 \pm 31.6$, and $0.131 \pm 35.6 \mathrm{ppm}$, respectively (Ruangwises et al., 2012). Thus it is found that arsenic concentration in the brown rice is greater than that of polished rice. However, the concentration of arsenic in Thai rice is almost the half of what we found in the rice collected from Comilla district of Bangladesh. 
This could be due to variation in the soil and water concentration of arsenic. Meanwhile, Islam et al. (2007) reported that the rice grain As concentration was in the range of $0.24-1.30 \mathrm{ppm}$ having a mean of $0.76 \mathrm{ppm}$. On the other hand, it is demonstrated that the agricultural soil of Matlab upazilla of Chandpur district become highly contaminated with arsenic due to excessive use of arsenic rich ground water $(1.85-5.02 \mathrm{mg} / \mathrm{kg})$. From the household survey, it was observed that daily water consumption by an adult ranged between 4-8 liter. Concentrations of arsenic in rice grain (with husk) from the contaminated field were varied from 0.01-0.15 $\mathrm{mg} / \mathrm{kg}$. Meanwhile, the rice grain (without husk) contained below the detection limit of $0.02 \mathrm{mg} / \mathrm{kg}$ of arsenic (Ahmed, 2009).

The present study was undertaken to detect and determine arsenic levels in animal feed chain by FI-HG-AAS method and found that the average arsenic concentration in broken rice and water hyacinth were $0.213 \pm 0.125$ $\mathrm{ppm}(\mathrm{n}=35)$ and $0.487 \pm 0.172 \mathrm{ppm}(\mathrm{n}=29)$, respectively. These levels of arsenic in grain and roughage is 4 times and 9 times greater than that of the maximum permissible level of arsenic in drinking water $(0.05 \mathrm{ppm}, \mathrm{WHO})$, respectively. Interestingly seed grain (e.g. broken rice) contains less arsenic than the roughage (e.g. water hyacinth). Whereas, animals are mainly fed on roughages, which contains alarming level of arsenic in the arsenic contaminated areas of Comilla district. As shallow tube well water is most frequently used for irrigation which is more contaminated with ground water arsenic than deep tube well water, it leads to arsenic contamination in animal feed chain. Therefore, to minimize or to avoid the risk of arsenic contamination in animal, irrigation should be done with deep tube well water or with natural water such as rain water, pond water and surface water. Animal should be prevented from grazing in the heavily contaminated areas. Instead of arsenic sensitive cultivars, arsenate tolerant cultivars of grain (rice, wheat, maize etc.) can be cultivated in the arsenic contaminated areas of our country. Moreover, phytoextraction by crop rotation can be practiced in arsenic contaminated crop lands. Cultivation of arsenic accumulating plants or crops can be followed by cultivation of rice or other grains. Phytoextraction is a remediation technology with a promising application for removing arsenic from soils and waters. Cucumis sativus (cucumber) has been found to be the best arsenic accumulating plant hence the best candidate plant for phytoextraction of arsenic from soil and water (Hong et al., 2011). Although it was beyond the scope of the present study, new innovative experiments should be designed to reduce the risk of toxic effect of arsenic in animal body by chemical and/ or herbal method, such as spirulina (Karim, 1999). The present study is an initial study. More research in this respect should be undertaken with the objective of mitigation of arsenic problem in Bangladesh to save the people as well as livestock.

\section{ACKNOWLEDGEMENTS}

The authors are grateful to the Cornell University, USA for the financial support that enabled them to carry out the research project "Detection of Arsenic in Crop-based Animal Food Chain and its Content in edible parts of Poultry" in the Department of Pharmacology, BAU, Mymensingh.

\section{REFERENCES}

1. Ahmed B (2009). Arsenic in food chain through irrigation water-soil-crop pathway; Risk assessment for sustainable agriculture of Bangladesh. An MSc thesis submitted to Department of Water and Environment, Swedish University of Agricultural Science (SLU), Uppsala, Sweden. Available at: hhtp://stud.epsilon.slu.se/1180/1/ahmed_b_100517.pdf

2. Bailey NTJ (1981). The use of t-test for some samples. Statistical Methods in Biology. $2^{\text {nd }}$ edn. Hodder and Stoughton. Great Britain.

3. Chakma S (2012). Detection of arsenic in animal feed chain: Rice and rice straw. An MS thesis submitted to Department of Pharmacology, Faculty of Veterinary Science, Bangladesh Agricultural University, Mymensingh-2202, and Bangladesh.

4. Chakraborti D, Rahman MM, Das B, Murrill M, Dey S, Mukherjee SC, Dhar RK, Biswas BK, Chowdhury UK, Roy S, Sorif S, Selim M, Rahman M and Quamruzzaman Q (2010). Status of groundwater arsenic contamination in Bangladesh: A 14-year study report. Water Research 44(19): 5789-5802.

5. Chigbo FE, Smith RW and Shore FI (1982). Uptake of arsenic, cadmium, lead and mercury from polluted water by the water hyacinth. Eichornia crassipes. Environmental Pollution Series A, Ecological and Biological 27: 31-36. 


\section{R. Haq and others}

6. Das HK, Chowdhory DA, Rahman S, Obaidullah, Miah MU, Sengupta P and Islam F (2002). Arsenic Contamination of Soil and Water and Related Bio-hazards in Bangladesh. Environmental International 30(3): 383-387.

7. Farid ATM, R Sen, Haque and Duxbury JM (2005). Arsenic status of water, soil, rice grain and straw of individual shallow tube well command area of Brahmanbaria. Available at: http://arsenic.tamu.edu/pub/ pubpres/DHAKA/ dhaka4.pdf.

8. Hong SH, Choi SA, Yoon H, Cho KS (2011). Screening of Cucumis sativus as a new arsenic-accumulating plant and its arsenic accumulation in hydroponic culture. Environmental Geochemistry and Health 33 Suppl 1:143-149.

9. Hossain MF (2006). Arsenic contamination in Bangladesh - An overview. Agriculture, Ecosystems \& Environment 113(1-4): 1-16.

10. Islam MR, Jahiruddin M and Islam S ( 2007). Arsenic linkage in the irrigation water soil rice plant systems. Pakistan Journal of Scientific and Industrial Research 50(2): 85-90.

11. Karim MA (1999). Study on the effect of Spirulina in the treatment of chronic arsenicosis in Bangladesh population. $1^{\text {st }}$ International conference of Dermatology Monograph, Dhaka, Bangladesh. May 8-10, Article no 13.

12. Kile ML, Houseman EA, Breton CV, Smith T, Quamruzzaman Q, Rahman M, Mahiuddin G and Christiani DC (2007). Dietary arsenic exposure in Bangladesh. Environmental Health Perspectives 115(6): 889-893.

13. Lau PY, Michalik P, Porter CJ and Krolik S (1987). Identification and confirmation of arsenobetaine and arsanocholine in fish, lobster and shrimp by a combination of fast atom bombardment and tandem mass spectrometry. Biomed. Environ. Mass Spectrom., 14: 723-732.

14. Ministry of Health and Family Welfare Bangladesh. Arsenic Contamination of Ground Water in Bangladesh. A Briefing Paper available at www.mohfw.gov.bd.

15. Naidu R, Smith E, Owens G, Akter K, Khan NI, Huq I and Rahman M (2006). Potential arsenic exposure pathways in Bangladesh. Paper Presented at $6^{\text {th }}$ International Conference on "Safe Water and Safe Food Options in Arsenic Mitigation: Lesson Learnt", held at 4-5 January, 2006, Dhaka, Bangladesh.

16. Rahman MA, Hasegawa H, Rahman MM, Rahman MA. and Miah MAM (2007). Accumulation of arsenic in tissues of rice plant (Oryza sativa L.) and its distribution in fractions of rice grain, Chemosphere 69(6): 942948.

17. Ruangwises S, Saipanp P, Tengiacroenkui B and Ruangwises N (2012).Total and inorganic arsenic in rice and rice bran purchased in Thailand. Journal of Food Protection 75(4): 771-774.

18. Samanta G, Chowdhury TR, Mandal BK, Biswas BK, Chowdhury UK, Basu GK, Chanda CR, Lodh D and Chakraborti D (1999). Flow injection hydride generation atomic absorption spectrometry for determination of arsenic in water and biological samples from arsenic-affected districts of West Bengal, India and Bangladesh. Microchemical Journal 62: 174-191.

19. Sapkota AR, Lefferts LY, McKenzie S and Walker P (2007). What do we feed to food production animals"? A review of animal feed ingredients and their potential impacts on human health. Environmental Health Perspectives 115(5): 663.

20. Wahidur R (2006). Arsenic Exposure in Bangladesh: The Reproductive and Developmental Health Effects in Humans. Philadelphia Annual Meeting held on 22-25 October, 2006. Paper No. 67-3.

21. Wang L, Xu ZR, Jia XY and Han XY (2006). Effects of dietary arsenic levels on serum parameters and trace mineral retentions in growing and finishing pigs. Biological Trace Element Research 113(2): 155-164.

22. Welch AH, Lico MS and Hughes JL (1988). Arsenic in groundwater of the Western United States. Ground Water, 26 (3): 333-347.

23. WHO (2001). Arsenic and Arsenic Compounds. $2^{\text {nd }}$ edn. Environmental Health Criteria 224.Geneva, World Health Organization. 